\title{
Pendampingan Penyusunan Soal Higher Order Thinking Bagi Guru Sekolah Dasar
}

\author{
Ika Maryani ${ }^{*}$, Sri Tutur Martaningsih ${ }^{1}$ \\ ${ }^{1}$ Program Studi PGSD, Universitas Ahmad Dahlan, Jl. Ki AgengPemanahan 19 Sorosutan, Yogyakarta 55162 \\ *Email: ika.maryani@pgsd.uad.ac.id
}

\begin{abstract}
Abstrak
Pendampingan Guru tentang sistem evaluasi pembelajaran berbasis higher order thinking skill merupakan bagian penting dari pengembangan kurikulum 2013 versi terbaru. Sesuai dengan strategi implementasi dari Kurikulum 2013, pelatihan ini direncanakan akan dilaksanakan pada awal tahun 2017 sampai saat ini. Strategi dimulai dengan melatih master of trainer (MOT) yang termasuk instruktur nasional, Dosen LPTK, Guru berprestasi tingkat Nasional, Pengawas, Kepala Sekolah berprestasi, Widyaiswara PPPPTK dan LPMP. Langkah berikutnya adalah melatih master trainer dari guru inti, pengawas, dan kepala sekolah baru kemudian dilanjutkan dengan pelatihan secara masal yang melibatkan guru mata pelajaran tingkat SD, SMP, dan SMA/SMK. Tahapan dari strategi kemendikbud ini tentu saja banyak hambatan. Sharing knowledge yang relatif lama dan kemungkinan-kemungkinan ketidakmerataan mungkin saja terjadi. Hal inilah yang mendorong Pengusul sebagai Dosen LPTK khususnya yang bergerak di bidang Pendidikan Dasar untuk ikut berpartisipasi dalam upaya pendampingan guru dalam menyusun soal berbasis higher order thinking skill. Upaya yang dilakukan adalah melalui pelatihan sistem evaluasi pembelajaran dn penyusunan soal berbasis higher order thinking skill. Program pendampingan ini sekaligus menjawab permasalahan yang terjadi pada mitra, dimana pemahaman para guru tentang sistem evaluasi pembelajaran berbasis higher order thinking skill masih sangat kurang. Guru belum mampu merencanakan soal berbasis HOTS serta melakukan analisis butir soal. Luaran yang diharapkan setelah program ini dilaksanakan adalah agar para guru mempunyai kemampuan teknis menyusun soal HOTS.
\end{abstract}

Kata kunci: Pendampingan, penyusunan soal, HOTS

\begin{abstract}
Teacher's assistance on higher order thinking skills based learning evaluation systems is an important part of developing the latest version of the 2013 curriculum. In accordance with the implementation strategy of the 2013 Curriculum, this training is planned to be held in early 2017 to the present. The strategy began by training a master of trainer (MOT) which included national instructors, LPTK lecturers, national-level outstanding teachers, supervisors, outstanding school principals, PPPPTK lecturers and LPMP. The next step is to train the master trainers from the core teachers, supervisors, and new school principals then proceed with mass training involving elementary, junior high, and high school / vocational school teachers. The stages of the Ministry of Education and Culture's strategy certainly have many obstacles. Knowledge sharing is relatively long and the possibilities for inequality may occur. This has encouraged Proposers as LPTK Lecturers, especially those engaged in Basic Education to participate in teacher assistance efforts in compiling questions based on higher order thinking skills. Efforts are being made through training in learning evaluation systems and drafting questions based on higher order thinking skills. This mentoring program also addresses the problems that occur in partners, where the understanding of teachers about the learning evaluation system based on higher order thinking skills is still lacking. The teacher has not been able to plan HOTS-based questions and do item analysis. The expected output after the program is implemented is that the teachers have the technical ability to compile HOTS questions.
\end{abstract}

Keywords: Assistance, preparation of questions, HOTS. 
Format Sitasi: Maryani, I., Martaningsih, S.T. (2020). Pendampingan Penyusunan Soal Higher Order Thinking Bagi Guru Sekolah Dasar. Jurnal SOLMA. Vol. 09(1): 156-166. Doi: http://dx.doi.org/10.29405/solma.v9i1.4100

Diterima: 15 Desember 2019 | Revisi: 27 Maret 2020 | Dipublikasikan: 30 April 2020.

(C) 2020 Oleh authors. Lisensi Jurnal Solma, LPPM-Uhamka, Jakarta. Artikel ini bersifat open access yang didistribusikan di bawah syarat dan ketentuan Creative Commons Attribution (CC BY) license. (http://creativecommons.org/licenses/by/4.0/).

\section{PENDAHULUAN}

Perubahan KTSP menjadi Kurikulum 2013 membutuhkan penyesuaian pola pikir para pemangku kepentingan (stake holder). Implementasi Kurikulum 2013 yang telah berjalan hampir satu tahun ini, mempunyai tantangan besar bagi para guru. Tantangan utamanya terletak pada pendekatan proses pembelajaran dan sistem evaluasi yang berpusat pada aktivitas siswa. Penerapan Kurikulum 2013 ini menuntut sekolah untuk memberikan ruang gerak yang luas supaya siswa dapat mengembangkan diri dan berinovasi (Sulisworo, Ishafit, Firdausy, \& Mada, 2014).

Pendekatan scientific yang menjadi basic proses pembelajaran harus menyentuh ranah afektif (sikap), ranah kognitif (pengetahuan), dan ranah psikomotor (keterampilan) (Maryani \& Fatmawati, 2018). Pendekatan scientific yang digunakan meliputi: menanya, menalar, mencoba, membentuk jejaring untuk semua mata pelajaran (Haerullah \& N., 2018). Hasil akhir yang diharapkan adalah peningkatan dan keseimbangan antara softskill dan hardskill peserta didik (Bell, Daniel, Kahrhoff, \& Jahna, 2006). Untuk mencapai hasil akhir tersebut, guru harus mampu mengubah mindset dari pola pembelajaran ala "bank" yaitu guru menjelaskan-siswa mendengarkan, menjadi proses pembelajaran yang lebih mengutamakan aktivitas siswa dalam melakukan pengamatan, bertanya, mencoba, mengeksplorasi, dan mengekspresikannya (Silberman, 2006).

Berbagai problematika klasik dalam pembelajaran menjadi masalah utama dalam penerapan pendekatan ini. Fakta di lapangan menunjukkan bahwa masih banyak praktik pembelajaran yang belum terpusat pada siswa. Guru masih mendominasi proses pembelajaran dan kurang memberi kesempatan siswa untuk mengeksplorasi diri (Huda, 2014). Guru juga kurang memfasilitasi siswa untuk berpikir kritis dan analitis dalam menyelesaikan masalah (Amirullah, Suciati, Handayani, \& Susilo, 2019). Permasalahan di atas juga terjadi pada sekolah mitra yang akan menjadi lokasi kegiatan pengabdian. 
PCM Minggir Kab. Sleman dipilih sebagai mitra mengingat reputasinya di bidang pendidikan sangat baik. PCM ini membawahi beberapa sekolah dasar dan dikoordinasi dengan baik sehingga dapat meminimalisir permasalahan yang timbul akibat lokasi yang berjauhan. Sebagian besar guru SD di bawah PCM Minggir Sleman juga merupakan guruguru muda sehingga diperkirakan akan mengikuti materi pelatihan dengan maksimal.

Kabupaten Sleman juga mempunyai jumlah sekolah yang cukup banyak, sehingga program pelatihan yang dilakukan oleh pemerintah belum menjangkau seluruh sekolah yang ada di sana. Sebaran sekolah dasar di lokasi mitra dapat dilihat pada Tabel 1 berikut.

Tabel 1. Sebaran jumlah sekolah dasar (SD) di Kabupaten Sleman

\begin{tabular}{cccccc}
\hline & $\begin{array}{c}\Sigma \text { seluruh } \\
\text { SD }\end{array}$ & $\begin{array}{c}\Sigma \text { SD } \\
\text { Negeri }\end{array}$ & $\begin{array}{c}\Sigma \text { SD } \\
\text { Swasta }\end{array}$ & $\begin{array}{c}\boldsymbol{\Sigma} \text { SD } \\
\text { Muhammadiyah }\end{array}$ & $\begin{array}{c}\Sigma \text { SD } \\
\text { Sasaran } \\
\text { K-13 }\end{array}$ \\
\hline Kab. Sleman & 498 & 381 & 117 & 76 & 13 \\
\hline
\end{tabular}

Data di atas menunjukkan adanya kesenjangan antara jumlah sekolah sasaran yang ditunjuk pemerintah dalam implementasi Kurikulum 2013 dengan jumlah total sekolah yang ada pada Kabupaten tersebut. Hal ini tentu saja menimbulkan masalah terkait dengan penyiapan guru untuk menerapkan Kurikulum 2013. Proses sosialisasi menjadi terkendala karena minimnya sumber daya manusia (guru inti) dari sekolah sasaran sebagai tim pelatih bagi guru-guru di sekolah lain. Program-program pelatihan dari pemerintah dirasa kurang maksimal karena belum mampu menyentuh seluruh sekolah, khususnya sekolah swasta. Keterbatasan dana pemerintah juga menjadi satu masalah pelik yang menyebabkan kurang maksimalnya penyiapan guru dalam menghadapi kurikulum 2013.

Guru-guru SD Negeri relatif lebih sering mendapat pelatihan terkait penerapan Kurikulum 2013 dibanding guru-guru di SD Swasta. Hal ini dikarenakan adanya keterbatasan program-program pemerintah untuk menjangkau seluruh elemen masyarakat. Untuk mengantisipasi hal tersebut, yayasan secara mandiri harus mengupayakan pelatihanpelatihan untuk guru mereka. Namun demikian, pelatihan yang selama ini dilaksanakan dirasa masih belum maksimal. Berdasarkan hasil diskusi dengan Majelis Dikdasmen Pimpinan Daerah Muhammadiyah (PDM) Kab. Sleman, pelatihan yang dilaksanakan oleh PDM masih bersifat terbatas. Hal ini dikarenakan guru inti yang dimiliki oleh PDM jumlahnya juga terbatas. Dari 76 SD Muhammadiyah di Kab. Sleman, guru inti hanya 
berasal dari 13 sekolah saja. Fakta ini semakin memperjelas adanya kesenjangan antara jumlah guru inti dengan guru yang harus dilatih untuk menerapkan Kurikulum 2013. Maka dari itu, diperlukan peran serta dari LPTK untuk membantu mengadakan pelatihanpelatihan dalam mengimplementasikan Kurikulum 2013.

Permasalahan lain yang dihadapi guru dalam implementasi Kurikulum 2013 adalah minimnya pemahaman tentang penilaian proses dan hasil belajar berbasis HOTS. Penilaian digunakan untuk mengetahui kekuatan dan kelemahan dalam proses pembelajaran yang telah dilakukan. Pada kurikulum 2013, sistem yang direncanakan adalah sistem penilaian yang berkelanjutan, artinya semua indikator ditagih, kemudian hasilnya dianalisis untuk menentukan KD yang telah dimiliki dan yang belum, serta untuk mengetahui kesulitan peserta didik (Kemdikbud, 2013). Penilaian harus dilakukan secara holistic terkait aspek sikap, pengetahuan, dan keterampilan. Pada jenjang pendidikan dasar, proporsi pembinaan karakter lebih utama dari pada proporsi akademik. Banyaknya teknik penilaian di SD menuntut guru untuk terampil menentukan dan mengembangkan instrumen penilaian untuk mengukur proses maupun hasil belajar (Supratiknya, 2012).

Fakta yang terjadi di lokasi mitra, banyak guru kesulitan untuk menggunakan teknik penilaian berbasis HOTS (Dewi, 2016; Retnawati, 2015; Sudarisman, 2015). Konsep belajar tuntas yang membutuhkan waktu lebih lama juga menuntut guru memahami kemampuan siswanya secara individu. Guru juga belum sepenuhnya paham tentang konsep penilaian otentik dan berkesinambungan. Teknik penilaian yang selama ini dilakukan juga belum bervariasi seperti yang dituntut oleh kurikulum 2013 (Kementrian Pendidikan dan Kebudayaan, 2014). Permasalahan di atas jika dibiarkan terus-menerus akan menjadi semakin besar dan berpotensi menghambat penerapan kurikulum 2013 di sekolah mitra. Oleh karena itu pelatihan tentang penilaian proses dan hasil belajar pada kurikulum 2013 harus secepatnya dilaksanakan, khususnya bagi guru-guru SD di Kab. Sleman.

Berdasarkan deskripsi hasil analisis masalah tersebut di atas, didapatkan situasi dan kondisi mitra yang dapat digolongkan dalam 2 aspek utama sebagai berikut:

1. Mitra memiliki keterbatasan di bidang sumber daya manusia (guru inti) untuk melatih para guru SD di lokasi mitra sehingga menyebabkan guru-guru SD swasta di dua kabupaten tersebut mengaku belum siap dalam menerapkan Kurikulum 2013.

2. Guru-guru di lokasi mitra mengalami kesulitan terhadap konsep penilaian berbasis HOTS yang digunakan dalam kurikulum 2013. Guru juga kurang terampil dalam 
mengembangkan instrumen penilaian proses dan hasil belajar sehingga penilaian yang selama ini dilakukan masih bersifat asal-asalan.

\section{MASALAH}

Berdasarkan pada analisis yang telah disebutkan sebelumnya, dapat diidentifikasi permasalahan mitra yaitu:

1. Permasalahan Umum adalah bahwa mitra mempunyai guru dengan latar belakang pendidikan guru yang bermacam-macam sehingga menyebabkan perbedaan pemahaman terhadap pendekatan scientific. Sebagian besar guru SD di lokasi mitra mengalami kesulitan dalam menerapkan pendekatan scientific baik di kelas awal maupun kelas tinggi dan sulit mengembangkan instrumen penilaian untuk mengukur proses dan hasil pembelajaran pada kurikulum 2013.

2. Permasalahan Khusus pada mitra adalah dibutuhkannya keterampilan dalam mengembangkan sistem penilaian proses dan hasil belajar. Sistem penilaian otentik belum dipahami oleh guru sehingga guru merasa kesulitan dalam menentukan dan mengembangkan instrumen penilaian. Oleh karena itu perlu dilakukan pelatihan untuk mengembangkan penilaian terhadap proses dan hasil belajar siswa yang sesuai dengan tuntutan Kurikulum 2013.

\section{METODE PELAKSANAAN}

Struktur program pelatihan dan pendampingan dilaksanakan dengan pola in service training yang dilakukan dalam pemaparan secara klasikal, serta pola on the job learning atau dilakukan pendampingan mandiri di tempat tugas peserta pelatihan sebagai implementasi pelatihan (Dube, 2018). Pola in service training dilakukan dalam 1 kali pelatihan selama 2 hari bertempat di SD Muhammadiyah Tengahan Sleman.

Kegiatan pelatihan direncanakan berdurasi 100 menit setiap sesinya. Pelatihan 1 terdiri dari 3 sesi. Sedangkan dalam kegiatan pendampingan berdurasi $100-150$ menit setiap sesinya, tergantung tingkat kesulitan materi pendampingan. Seluruh materi pelatihan dan pendampingan disajikan dalam modul berbentuk hardcopy yang sudah digandakan dan dibagikan pada peserta sebelum dilaksanakan program. Pendekatan yang digunakan dalam pelatihan berbasis keaktifan peserta, sehingga peserta tidak hanya pasif menerima transfer materi dari para trainer tapi justru aktif membuat produk. Dalam program ini, PCM Minggir 
selaku mitra berperan memberikan partisipasi utamanya sebagai peserta dari setiap pelatihan maupun aktivitas pengabdian yang diusulkan serta menerapkan pengetahuan dari pelatihan pada sekolahnya masing-masing.

Keberhasilan pendampingan ditandai dengan meningkatnya pemahaman dan keterampilan guru tentang konsep penilaian HOTS dan perancangan instrument penilaian HOTS. Sebagai bentuk keberlanjutan program, dirintis MoU antara PCM Minggir dengan Prodi PGSD UAD yang fokus pendampingan secara berkelanjutan tentang pengelolaan kelas bagi guru-guru SD di PCM Minggir dibawah koordinasi prodi PGSD.

\section{PEMBAHASAN}

Tahap pertama dalam program ini adalah observasi dan wawancara untuk menganalisis masalah yang ada di mitra. Observasi dan wawancara dilakukan sebelum menyusun proposal PKM. Tahap selanjutnya setelah tanda tangan kontrak PPM yaitu koordinasi pelaksanaan PPM dengan mitra. Dalam hal ini diwakili oleh kepala sekolah SD Muhammadiyah Sragan sebagai koordinator. Koordinasi dilaksanakan pada hari Jumat, 5 Juli 2019. Koordinasi menjadi bagian yang esensial dalam pelaksanaan PPM agar terjalin hubungan yang harmonis antara tim dengan mitra, selain itu masalah yang mitra dapat terselesaikan dengan tepat sasaran. Hal yang dibahas dalam koordinasi yaitu kurikulum pelatihan terdiri dari materi dan jam pelatihan, teknis pelaksanaan pelatihan antara lain waktu dan tempat pelatihan, jumlah peserta, perwakilan SD yang terlibat, tamu undangan. Tingginya animo peserta, membuat jumlah peserta bertambah. Dari yang semula peserta pelatihan terbatas pada lingkup PCM Minggir kemudian diperluas hingga gugus-gugus sekitar sehingga mencapai 65 guru. Pelatihan dilaksanakan dalam 2 hari pada tanggal 24-25 Juli 2019. Kurikulum pelatihan telah berhasil disusun seperti pada Tabel 2.

Tabel 1. Kurikulum Pelatihan Penyusunan Soal HOTS

\begin{tabular}{llc}
\hline No & \multicolumn{1}{c}{ Materi } & JP \\
\hline 1. & Prakondisi & 1 \\
2. & Konsep Higher Order Thinking Skills & 3 \\
3. & Penilaian Berbasis Higher Order Thinking Skills & 3 \\
4. & Penyusunan Soal HOTs & 3 \\
5. & Pembelajaran Berbasis Higher Order Thinking Skills & 3 \\
6. & Refleksi dan Tindak Lanjut & 2 \\
& Total & 15 \\
\hline
\end{tabular}


Pelatihan hari pertama dilaksanakan dari Hari Rabu, 24 Juli 2019 pukul 08.00 - 16.00 WIB dengan materi Konsep Higher Order Thinking Skill. Materi diisi oleh M. Fakhrur Saifudin, M.Pd. Pada pertemuan awal diberikan brainstorming tentang Kurikulum 2013, karena penilaian HOTs sangat erat kaitannya dengan tatangan Kurikulum 2013. Materi selanjutnya yaitu Penilaian Berbasis HOTs. Pada materi ini diberikan contoh-contoh soal HOTs serta bagaimana menyusunnya.
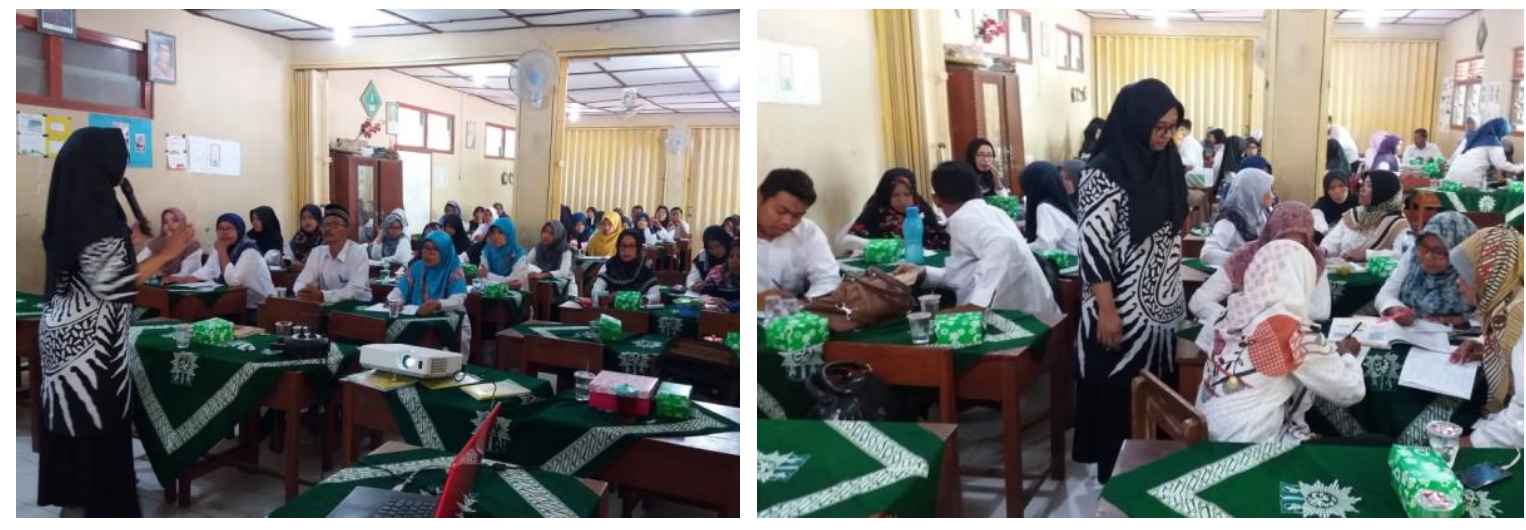

Gambar 1. Materi Konsep Penilaian Gambar 2. Aktivitas Peserta dalam Berbasis HOTs

Mengerjakan Lembar Kerja

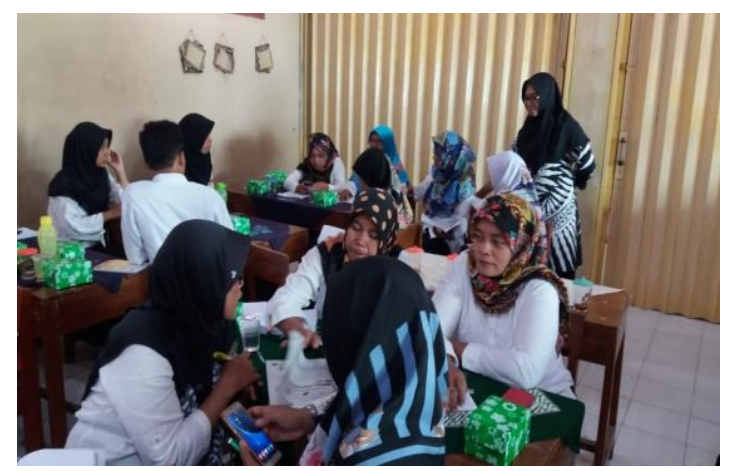

Gambar 3. Peserta Permasalahan HOTs

Berdiskusi Penilaian

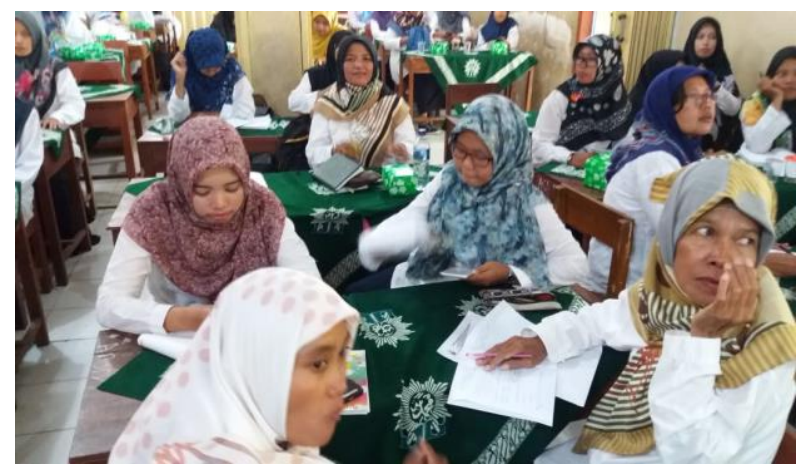

Gambar 4.
Peserta Praktek Membuat Soal HOTs

Pelatihan hari kedua dilaksanakan hari Kamis, 25 Juli 2019 pukul 08.00 - 16.00 WIB dengan materi Penyusunan Soal HOTs dan Pembelajaran berorientasi HOTs. Pada pertemuan kedua ini antusian peserta semakin meningkat karena metode yang digunakan hands on learning. Peserta langsung praktik membuat soal HOTs secara berkelompok. Setelah membuat soal kemudian dilanjutkan presentasi. Hasil yang diperoleh yaitu bertambahnya kemampuan guru dalam membuat soal HOTs. Hal ini bermanfaat sekali 
apabila diterapkan pada pembelajaran di kelas. Mahasiswa akan dilibatkan dalam kegiatan pendampingan berperan sebagai co trainer terutama saat mendampingi peserta berdiskusi. Setelah pelatihan selesai disebar angket evaluasi untuk mengetahui respon peserta terhadap hasil pelatihan. Angket evaluasi terdiri dari 30 pertanyaan tertutup dengan 4 skala (1 s.d 4).

Tabel 2. Pernyataan dalam Angktet

\section{Pernyataan}

1. Pelatihan ini membantu saya untuk lebih cepat memahami materi.

2. Pelatihan ini memberi peluang untuk lebih produktif dalam bekerja.

3. Pelatihan ini sangat berguna.

4. Pelatihan ini memberi kesempatan untuk mengatur kemandirian belajar saya.

5. Pelatihan ini menjadikan saya lebih mudah menyelesaikan tugas-tugas.

6. Pelatihan ini dapat memperbaiki metode mengajar saya

7. Pelatihan ini sesuai dengan kebutuhan yang saya harapkan.

8. Pelatihan ini memberikan berbagai hal yang saya harapkan dalam belajar

9. Saya merasa strategi yang digunakan oleh trainer dalam pelatihan ini mudah diterapkan

10. Aktivitas- aktivitas yang ditunjukkan dalam pelatihan ini tidak sulit untuk dilakukan

11. Kegiatan - kegiatan yang digunakan dalam Pelatihan ini memungkinkan untuk diterapkan

12. Tahapan dalam menyelesaikan tugas-tugas sudah sangat sederhana bagi saya.

13. Sistem yang digunakan dalam pelatihan ini fleksibel untuk dikembangkan

14. Untuk memahami sistem yang digunakan dalam pelatihan ini tidak terlalu sulit.

15. Semua aktivitas dan program yang digunakan dalam pelatihan sudah konsisten.

16. Saya senang dengan strategi pelatihan ini untuk diterapkan dalam kegiatan di sekolah maupun di luar sekolah

17. Saya dapat segera menyesuaikan diri dengan mudah dan cepat terhadap materi pelatihan ini

18. Saya dapat menggunakan modul/bahan ajar yang digunakan dalam pelatihan ini dengan mudah.

19. Saya dapat dengan cepat mempelajari metode yang digunakan dalam Pelatihan.

20. Saya mudah menerapkan bagaimana metode yang digunakan dalam pelatihan ini.

21. Saya mudah mempelajari bagaimana menggunakan metode dalam pelatihan.

22. Dengan cepat saya dapat menguasai materi yang disampaikan dalam pelatihan ini

23. Saya dapat dengan mudah mengimplementasikan hasil pelatihan sesuai dengan petunjuk yang disampaikan oleh pelatih.

24. Saya merasa puas dengan pelatihan yang dilakukan

25. Saya akan memberitahu teman lain bahwa pelatihan ini baik.

26. Pelatihan ini menyenangkan bagi saya

27. Dengan pelatihan ini saya dapat mengerjakan tugas sebagai guru sesuai yang saya harapkan

28. Pelatihan ini sangat menarik minat belajar saya

29. Saya merasa senang dengan cara trainer mengajar

30. Pelatihan ini nyaman diterapkan untuk berbagai situasi belajar 
Evaluasi ini dilaksanakan dengan tujuan untuk mendapatkan umpan balik dari peserta. Program dikatakan berhasil jika rerata skor masing-masing pertanyaan minimal 3. Hasil evaluasi pelatihan tersaji pada Gambar 8 .

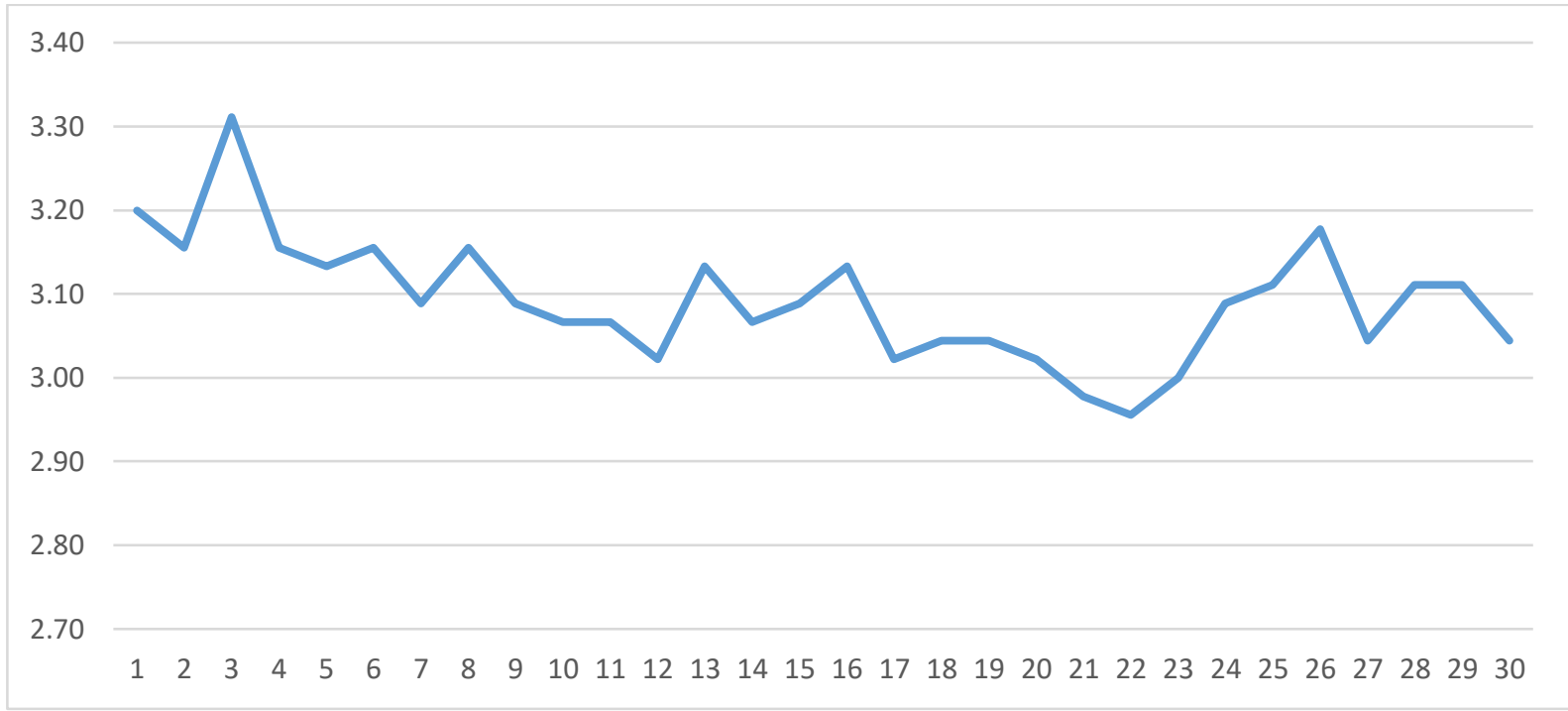

Gambar 5. Hasil Evaluasi Pelatihan Penyusunan Soal HOTS

Gambar 5. memperlihatkan hasil evaluasi pelatihan yang ditunjukkan dengan 30 indikator keberhasilan sebagai. Hasil evaluasi dari peserta pelatihan menyimpulkan bahwa pelatihan membuat peserta lebih cepat memahami materi, pelatihan memberi peluang untuk lebih produktif dalam bekerja, pelatihan ini sangat berguna dalam memberi kesempatan untuk mengatur kemandirian belajar, menjadikan lebih mudah menyelesaikan tugas-tugas, memperbaiki metode mengajar, dan sesuai dengan kebutuhan yang diharapkan. Pelatihan ini memberikan berbagai hal yang diharapkan dalam belajar, Strategi pelatihan yang digunakan oleh trainer dalam pelatihan ini mudah diterapkan, aktivitas- aktivitas yang ditunjukkan dalam pelatihan ini tidak sulit untuk dilakukan, kegiatan - kegiatan yang digunakan dalam Pelatihan ini memungkinkan untuk diterapkan, tahapan dalam menyelesaikan tugas-tugas sudah sangat sederhana,sistem yang digunakan dalam pelatihan ini fleksibel untuk dikembangkan,untuk memahami sistem yang digunakan dalam pelatihan ini tidak terlalu sulit (Sadik \& Sadik, 2014). Semua aktivitas dan program yang digunakan dalam pelatihan sudah konsisten, senang dengan strategi pelatihan ini untuk diterapkan dalam kegiatan di sekolah, dapat segera menyesuaikan diri dengan mudah dan cepat terhadap materi pelatihan ini. Namun demikian, pada bagian kecepatan pemahaman peserta terhadap 
materi, dapat terlihat bahwa rerata skornya di bawah 3.00 sehingga pada bagian ini masih perlu ditingkatkan lagi.

\section{KESIMPULAN}

Program pelatihan penyusunan soal HOTs bagi guru SD di Kecamatan Minggir, Sleman telah berhasil dilaksanakan. Program ini mampu meningkatkan pengetahuan dan keterampilan guru dalam mengembangkan instrument penilaian berbasis HOTs. Rekomendasi yang dapat diberikan adalah agar metode pelatihan dibuat lebih efektif untuk memudahkan peserta memahami materi pelatihan.

\section{UCAPAN TERIMA KASIH}

Terimakasih kepada LPPM UAD yang telah membiayai seluruh program ini melalui Hibah Pengabdian kepada Masyarakat dan juga PCM Kecamatan Minggir sebagai mitra.

\section{DAFTAR PUSTAKA}

Amirullah, G., Suciati, R., Handayani, D., \& Susilo, S. (2019). The Impact of Predict Observe Explain ( POE ) strategy against student's s critical thinking ability. Biodik: Jurnal Ilmiah Pendidikan Biologi, 5(2), 173-180.

Bell, Daniel, Kahrhoff, \& Jahna. (2006). Active Learning Handbook.

Dewi, F. (2016). Proyek Buku Digital: Upaya Peningkatan Keterampilan Abad 21 Calon Guru Sekolah Dasar Melalui Model Pembelajaran Berbasis Proyek. Metodik Didaktik, $9(2)$.

Dube, S. (2018). The 21st Century Students' Educational Ict Preferences. International Robotics \& Automation Journal, 3(5), 3-6. https://doi.org/10.15406/iratj.2017.03.00069

Haerullah, A., \& N., A. Z. (2018). Analisis Kompetensi Pedagogik... Haerullah dan ZN 1. Jurnal Biologi Dan Pembelajarannya, 5(2), 1-7.

Huda, M. (2014). Model-Model Pengajaran dan Pembelajaran. Yogyakarta: Pustaka Pelajar.

Kemdikbud. (2013). Panduan Teknis Penilaian di Sekolah Dasar. Retrieved from Pedoman pemberian Bantuan Implementasi Kurikulum 2013. Diakses pada tanggal 18 April 2013 dari disdikporakuningan.net/unduh/pedoman_kur_13.pdf\%0A

Kementrian Pendidikan dan Kebudayaan. (2014). Konsep dan Implementasi Kurikulum 2013. (1st ed.). Jakarta: Kementrian Pendidikan dan Kebudayaan.

Maryani, I., \& Fatmawati, L. (2018). Pendekatan scientific dalam pembelajaran di sekolah dasar: teori dan praktik. Yogyakarta: Deepublish. 
Retnawati, H. (2015). Hambatan guru matematika sekolah menengah pertama dalam menerapkan kurikulum baru. Cakrawala Pendidikan, 3 .

Sadik, F., \& Sadik, S. (2014). A Study on Environmental Knowledge and Attitudes of Teacher Candidates. Procedia - Social and Behavioral Sciences, 116, 2379-2385. https://doi.org/10.1016/j.sbspro.2014.01.577

Silberman, M. (2006). Active Learning: 101 Cara Belajar Siswa Aktif. Bandung: Penerbit Nusa Media dan Penerbit Nuansa.

Sudarisman, S. (2015). Memahami Hakikat Dan Karakteristik Pembelajaran Biologi Dalam Upaya Menjawab Tantangan Abad 21 Serta Optimalisasi Implementasi Kurikulum 2013. Florea: Jurnal Biologi Dan Pembelajarannya, 2(1), 29-35. https://doi.org/10.25273/florea.v2i1.403

Sulisworo, D., Ishafit, I., Firdausy, K., \& Mada, U. G. (2014). Indonesian Journal of Curriculum and. (October).

Supratiknya, A. (2012). Penilaian hasil belajar dengan teknik nontes. Yogyakarta: Universitas Sanata Dharma. 